\title{
Nitrate Accumulation and Oxalate Formation in Spinach Plants (Spinacia oleracea, L.) as Affected by Nitrogen Fertilization levels and Iron Foliar Application. Fatma M. Ghaly ${ }^{1}$; G. A. Baddour ${ }^{2}$ and Hind M. El-Azazy ${ }^{2}$ \\ ${ }^{1}$ Soils Dept., Fac. of Agriculture, Damietta Univ., Egypt. \\ ${ }^{2}$ Plant Nutrition Dept., Soil, Water and Enviro. Res, Inst., Agric. Res. Center.
}

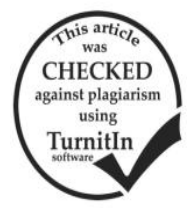

\section{ABSTRACT}

Two field experiments were organized at the Tag Elez Station Experimental Farm; Governorate of Dakahlya, during the two successive winter seasons of 2014-2015 and 2015-2016 using spinach plant (Spinacia oleracea, L. cv. "Balady"). Spinach seeds were sown on $2^{\text {nd }}$ and $6^{\text {th }}$ of December, seasons 2014 and 2015 , respectively. Ten treatments were arranged in split plot design with 3 replicates to evaluate the combination effect of five levels of $\mathrm{N}$-fertilizer $\{50,75,100,125$ and $150 \%\}$ from the recommended dose (RD) by the Ministry of Agric. and Soil Recl. (MASR) in the form of $\mathrm{NH}_{4} \mathrm{NO}_{3}(33.5 \% \mathrm{~N})$ as soil application in the presence and absence of $\mathrm{Fe}$ as foliar way $\mathrm{FeSo}_{4}(20 \% \mathrm{Fe})$ was used as a source of $\mathrm{Fe}$ at the rate of $300 \mathrm{ppm} \mathrm{Fe}$. The obtained results indicated that: * A nitrogen fertilizer application at the rates of this survey significantly increased the average values of dry weigh, chlorophyll contents, N, P, K, Fe and VC in the leaves of spinach plant tell the rate of $100 \% \mathrm{RD}$. increasing the rate of $\mathrm{N}$-fertilizer from $100 \%$ to $150 \%$ RD significantly decreased the mean values of all the aforementioned traits during both seasons of the experimentation. At any level of $\mathrm{N}$-fertilization; foliar applied of Fe has been recorded a pronounced high effects on the average values of all parameters under the current study. ${ }^{*}$ Increasing the rate of $\mathrm{N}$-fertilization from 50 to $150 \% \mathrm{RD}$ sharply and significantly increased the average value of nitrate and nitrite accumulation in spinach leaves, while such effect significantly decreased the activity of nitrate reductase enzyme in spinach plant. Moreover, foliar application of Fe in combination with any rate of $\mathrm{N}$-fertilizer has been corrected this trend. * A favorable effect on oxalate formation in spinach leaves due to an addition of iron in foliar way combined with any level of $\mathrm{N}$-fertilization as compared to the plants treated with the same levels of nitrogen in single form.

Keywords: $\mathrm{NH}_{4} \mathrm{NO}_{3}$, nitrite, nitrate, Oxalate, Iron, spinach.

\section{INTRODUCTION}

Spinach (Spinacia oleracea L.) is one of the vegetables whose leaves and stems are utilized processed or fresh. This plant produces large measures of fresh leafy mass in a short time of vegetation. Spinach is a restorative and appetizing plant that contains vitamins, antioxidants (flavonoids and ascorbic acid) and nutrients. It has been likewise recognized as one of the vegetables having innately high nitrate fixation and its petioles have a few fold higher concentration than its leaf blades. High concentration of nitrate and arrangement of oxalate are found in leafy vegetables for all intents and purposes under application of nitrogen treatment (Dehkharghanian et al., 2010).

Nitrogen is important for plant growth, it is a constituent of all proteins and nucleic acids, some of the plant growth regulators, and in many of the vitamins and hence of call protoplasm. As a component of these and many other compounds, nitrogen is involved in most of the biochemical reactions that compose life. An addition of huge amount of nitrogen to leafy vegetables such as cabbage, lettuce radish and spinach to maintain bright green color of the foliage and maximum yield, can lead to the accumulation of excessive levels of $\mathrm{NO}_{3}-\mathrm{N}$ in the plant. In Egypt, farmers consume a large amount of $\mathrm{N}$-fertilizers aiming to increase the yield without any care of the bad residual effect on the quality of crops Abd-Allah, (2001).

Nitrate is essential to life but a nuisance and possibly a hazard. Nitrate can be changed into nitrite by microbes requiring oxygen. This can happen in the soil, in water and in our bodies. When that happen in our bodies we have to consider two problems methaemoglobinaemia or the blue syndrome and stomach cancer. $\mathrm{No}_{3}{ }_{3}^{-}$ions in the soil usually complexed with the production of some pesticides degradation like amino compounds to produce nitrosamine compounds were carthenogenic to human and animals. The critical level recommended by FAO (2000) amounted $3.6 \mathrm{mg} \mathrm{day}^{-1}$ for ( a $60-\mathrm{kg}$ person) for nitrite.
Another factor governing the $\mathrm{NO}_{3}-\mathrm{N}$ accumulation in the vegetables is the status of micronutrients in plant especially Fe. In the case of insufficient concentration of $\mathrm{Fe}$ in plant, the application of this element will decrease $\mathrm{NO}_{3}-\mathrm{N}$ accumulation. This effect may be due to the role played by iron on $\mathrm{NO}_{3}$ and $\mathrm{NO}_{2}$ reductases activity. In this respect, Crawford and Campbell, (1990) reported that $\mathrm{NO}_{3}$ was first transported into the cell and then reduced to $\mathrm{NH}_{4}$ by the consecutive action of two enzymes $\mathrm{NO}_{3}$ - reductase and $\mathrm{NO}_{2}$ reductases. Both enzymes were metalloflavoprotein the enzyme system includes a reduced pyridine nucleotide (NADPH or NADH) as electron donor, flavin adenine dinucleotide (FAD) as a prosthetic group and an iron-containing hydrochlorine (siroheme) for $\mathrm{NO}_{2}-$ reductase.

Oxalate in vegetables is one of toxin and antinutrient. Free oxalic acid and soluble oxalate able to combine with $\mathrm{Ca}^{++}$and other mineral resulting in other foods deficiencies of $\mathrm{Ca}, \mathrm{Fe}, \mathrm{Mg}$ and $\mathrm{Cu}$. Uptake of oxalate-accumulating vegetables, such as spinach, can led to kidney stone formation due to actuating a huge increment in urinary oxalate excretion. Furthermore, abundance oxalate ingested in human bodies can cause afunctional hypocalcemia with tetany in intense cases and acute poisoning of oxalate. A deadly dose of oxalic acid arranged from 2 to $30 \mathrm{~g}$ was conducted for people depending on variety of factors and 2 grams of oxalate was the minimum lethal dose for human adult (Nakata, 2003; Bohn et al., 2004 and Massey, 2007).

Therefore, the objective of this study are to investigate nitrate accumulation and oxalate formation in spinach plants (Spinacia oleracea, L.) as affected by nitrogen fertilization levels and foliar iron application.

\section{MATERIALS AND METHODS}

Two field experiences were conducted at Tag Elez Station Experimental farm; Governorate of Dakahlya, during the two successive winter season of 2014-2015 and 
2015-2016 using spinach plant (Spinacia Oleracea, cv. "Balady"). Spinach seeds were sown on $2^{\text {nd }}$ and $6^{\text {th }}$ of December, 2014 and 2015 seasons, respectively. Soil sample was air dried and analyzed to determine some physical and chemical properties as shown in Table 1 .

Table 1. Some physical and chemical properties of the experimental soil during both seasons of 2014-2015 and 2015-2016

\begin{tabular}{|c|c|c|c|}
\hline \multicolumn{2}{|c|}{ Soil Properties } & $\begin{array}{c}\text { Season } \\
\text { 2014-2015 }\end{array}$ & $\begin{array}{c}\text { Season } \\
2015-2016\end{array}$ \\
\hline \multirow{5}{*}{$\begin{array}{l}\text { Mechanic } \\
\text { al } \\
\text { analysis } \\
\%\end{array}$} & Coarse Sand & 3.75 & 4.53 \\
\hline & Fine Sand & 30.04 & 29.36 \\
\hline & Silt & 39.12 & 39.82 \\
\hline & Clay & 27.09 & 26.29 \\
\hline & Texture class & Sandy clay loam & Sandy clay loam \\
\hline \multicolumn{2}{|c|}{ Organic matter \% } & 1.83 & 1.75 \\
\hline \multicolumn{2}{|c|}{$\mathrm{CaCO}_{3} \%$} & 4.51 & 4.39 \\
\hline \multicolumn{2}{|c|}{$\mathrm{pH} *(1: 2.5)$} & 8.12 & 8.14 \\
\hline \multicolumn{2}{|c|}{ E.C dS m} & 9.85 & 9.55 \\
\hline \multicolumn{2}{|l|}{ SP \% } & 53.5 & 52.1 \\
\hline \multirow{2}{*}{$\begin{array}{l}\text { Soluble } \\
\text { cation }\end{array}$} & $\mathrm{Ca}^{+2}$ & 2.05 & 2.01 \\
\hline & $\mathrm{Mg}^{+2}$ & 1.43 & 1.44 \\
\hline $\mathrm{meq} / 100 \mathrm{~g}$ & $\mathrm{Na}^{+}$ & 6.22 & 6.24 \\
\hline soil & $\mathrm{K}^{+}$ & 0.39 & 0.29 \\
\hline \multirow{4}{*}{$\begin{array}{l}\text { Soluble } \\
\text { anions } \\
\text { meq/100g } \\
\text { soil }\end{array}$} & $\mathrm{Co}_{3}{ }^{-2}$ & -- & -- \\
\hline & $\mathrm{HCO}_{3}^{-}$ & 2.25 & 2.03 \\
\hline & $\mathrm{Cl}^{-}$ & 5.93 & 6.03 \\
\hline & $\mathrm{So}_{4}^{-2}$ & 1.91 & 1.92 \\
\hline \multirow{5}{*}{$\begin{array}{l}\text { Available } \\
\text { ppm }\end{array}$} & $\mathrm{N}$ & 48.6 & 41.8 \\
\hline & $\mathrm{P}$ & 3.75 & 2.98 \\
\hline & K & 184 & 179 \\
\hline & $\mathrm{Fe}^{* *}$ & 3.41 & 3.34 \\
\hline & Mo ** & 0.169 & 0.156 \\
\hline
\end{tabular}

* Soil suspension 1:2.5 (soil: water)

** extracted by DTPA

Experimental design: Ten treatments were organized in a split plot design or two factorials with 3 replicates, to evaluate the combination effect of five levels of $\mathrm{N}$ fertilizer $(50,75,100,125$ and $150 \%)$ from the recommended dose (RD) by the Ministry of Agric. and Soil Recl. (MASR) in the form of $\mathrm{NH}_{4} \mathrm{NO}_{3}(33.5 \% \mathrm{~N})$ as a soil application in the presence and absence of $\mathrm{Fe}$ as a foliar way, $\mathrm{FeSo}_{4}(20 \% \mathrm{Fe})$ was used as a source of $\mathrm{Fe}$ at the rate of $300 \mathrm{ppm} \mathrm{Fe}$.

$\mathrm{N}$ doses were divided into two equal parts; the first addition was done after 21 days from sowing and the second one 15 days later. Foliar application of $\mathrm{Fe}$ was done at the same time of nitrogen fertilizer addition.

All cultivation processes were carried out according to the recommendation of the Egyptian Ministry of Agriculture.

Cultivation: Six meters square $(2 \times 3 \mathrm{~m})$ of plots were built-up. Five rows in each plot. Spinach seeds cv. Balady were sown on $2^{\text {nd }}$ and $6^{\text {th }}$ of December, 2014 and 2015 seasons, respectively; in hills; $15 \mathrm{~cm}$ apart on both sides of rows. After 21 days from planting; the plants were thinned at three plants per hill.

Experimental procedures: At harvesting stage (60 days after sowing of spinach, samples of twenty plants were taken at random from each experimental plot. plant parameters expressed in; Fresh weight $\left(\mathrm{g} \mathrm{Plant}^{-1}\right)$, dry weight $\left(\mathrm{g} \mathrm{Plant}^{-1}\right)$ and chlorophyll contents $\left(\mathrm{mg} \mathrm{g}^{-1}\right)$. Fresh weight of plant was determined as the average weight per plant in grams and then, $\mathrm{NO}_{3}-\mathrm{N}, \mathrm{NO}_{2}-\mathrm{N}$ content, the activity $\mathrm{NO}_{3}$-reductase enzyme, vitamin $\mathrm{C}$, total oxalate, soluble oxalate and insoluble oxalate were determined. Plant sample were oven dried and then; chemical analysis of plant expressed in $\mathrm{N}, \mathrm{P}$ and $\mathrm{K} \%$ as well as Fe ppm were estimated.

Soil methods of analysis: Mechanical analysis of the used soil was determined following the international pipette method Piper, (1950).

Calcium carbonate, organic matter, available $\mathrm{N}$, $\mathrm{P}, \mathrm{K}$, in soil were determined using the methods adopted by Dewis and Fertais, (1970); Jackson, (1967); Bremner and Mulvany, (1982); Olsen and Sommers, (1982) and Black, (1965), respectively.

EC and pH: were measured according to the method of US Salinity Lab (1954) and Jackson (1967). Iron in the soil was extracted using DTPA and determined by an Atomic Absorption Spectrophotometer as described by Chapman and pratt (1961).

Plant analysis: The oven dry materials of plant samples were ground and wet digested as described by Gotteni et al., (1982). The total N, P, K and Fe were determined using the techniques described by Jones et al., (1991); Peters et al., (2003); Black, (1965) and Chapman and Pratt, (1961), respectively.

Nitrate and nitrite were measured by using a rapid method of Singh (1988). Nitrate reductase enzyme activity described by Hageman and reed, (1980).

Chlorophyll content, Vitamin C, Total oxalate and soluble oxalate contents were determined according to the method of Sadasivam and Manickam, (1996); Mazumdar and Majumder, (2003) and Zhang et al., (2005), respectively.

Statistical analysis: The statistical analysis of the data collected was carried out according to the method described by (Gomez and Gomez 1984) using LSD to compare the means of treatment values.

\section{RESULTS AND DISCUSSION}

\section{Results}

Data illustrated in Table 2, the effect of $\mathrm{N}$ levels as soil fertilization and $\mathrm{Fe}$ as foliar application on fresh, dry weight ( $\mathrm{g}$ plant $^{-1}$ ) and the average values of chlorophyll $\left(\mathrm{a}, \mathrm{b} \&\right.$ total $\mathrm{mg} \mathrm{g}^{-1}$ ) for spinach plant at marketing stage.

Concerning the $\mathrm{N}$-fertilization levels studied affected in single form; data in Table 2 indicated that; the average values of all the parameters studied (except

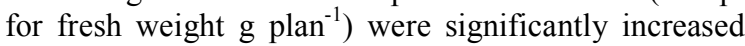
when the fertilization rate $\mathrm{N}$ increased by $100 \% \mathrm{~N}$. Increase the rate of $\mathrm{N}$-fertilization from $100 \%$ to 125 or $150 \% \mathrm{~N}$ significantly decreased the mean values of all the aform mentioned traits. The same trend realized in the $2^{\text {nd }}$ season of the experiment. In this connect the mean values of fresh weight $\mathrm{g}$ plan $^{-1}$ were significantly increased as the rate of $\mathrm{N}$-fertilization was increased from 50 to $125 \%$ from the recommended dose.

The effect of $\mathrm{Fe}$ as foliar way on the plant parameters under the presented study are shown in the same Table. It can be observed that; the best plant parameters were obtained by spinach plant treated with $\mathrm{Fe}$ at any level of $\mathrm{N}$-fertilization as compared to the untreated plants. On the other hand; the same trend of $\mathrm{N}$-fertilization 
levels in the absence of $\mathrm{Fe}$ foliar spraying was reflected on the average values of all the previously mentioned traits in the presence of Fe foliar applied. This trend was the same during both seasons of 2014-2015 and 2015-2016.

Table 2. Effect of nitrogen fertilization levels and Fe as foliar way on fresh, dry weight and the average values of chlorophyll of spinach plant during 2014-2015 and 2015-2016 seasons.

\begin{tabular}{|c|c|c|c|c|c|c|c|c|c|c|c|}
\hline \multirow{2}{*}{\multicolumn{2}{|c|}{ Treatments }} & \multicolumn{2}{|c|}{$\begin{array}{c}\text { Fresh Weight } \\
\left(\text { g plant }{ }^{-1}\right)\end{array}$} & \multicolumn{2}{|c|}{$\begin{array}{l}\text { Dry Weight } \\
\left.\text { (g plant }^{-1}\right)\end{array}$} & \multicolumn{2}{|c|}{$\begin{array}{c}\text { Chlorophyll a mg } \\
\text { g }^{-1} \text { FW }\end{array}$} & \multicolumn{2}{|c|}{$\begin{array}{c}\text { Chlorophyll b } \\
\text { mg g }^{-1} \text { FW }\end{array}$} & \multicolumn{2}{|c|}{$\begin{array}{l}\text { Total chlorophyll } \\
\operatorname{mg~g}^{1} \text { FW }\end{array}$} \\
\hline & & $1^{\text {st }}$ & $2^{\text {nd }}$ & $1^{\text {st }}$ & $2^{\text {nd }}$ & $1^{\text {st }}$ & $2^{\text {nd }}$ & $1^{\text {st }}$ & $2^{\text {nd }}$ & $1^{\mathrm{st}}$ & $2^{\text {nd }}$ \\
\hline \multirow{2}{*}{$50 \%$} & 0 & 36.43 & 46.17 & 5.04 & 6.54 & 0.511 & 0.568 & 0.322 & 0.408 & 0.833 & 0.976 \\
\hline & $\mathrm{Fe}$ & 59.83 & 69.33 & 7.98 & 9.80 & 0.603 & 0.668 & 0.405 & 0.497 & 1.008 & 1.164 \\
\hline \multirow{2}{*}{$75 \%$} & 0 & 38.43 & 52.20 & 5.65 & 7.42 & 0.528 & 0.594 & 0.435 & 0.431 & 0.963 & 1.025 \\
\hline & $\mathrm{Fe}$ & .07 & 74.27 & 8.57 & 10.45 & 0.622 & 0.684 & 0.414 & 0.511 & 1.036 & 1.196 \\
\hline \multirow{2}{*}{$100 \%$} & 0 & 40.40 & 54.63 & 5.91 & 7.70 & 0.569 & 0.605 & 0.423 & 0.441 & 0.992 & 1.046 \\
\hline & $\mathrm{Fe}$ & 65.40 & 76.17 & 8.87 & 10.69 & 0.635 & 0.694 & 0.426 & 0.521 & 1.062 & 1.215 \\
\hline \multirow{2}{*}{$125 \%$} & 0 & 42.73 & 56.00 & 5.33 & 7.13 & 0.516 & 0.583 & 0.327 & 0.423 & 0.843 & 1.006 \\
\hline & $\mathrm{Fe}$ & 66.60 & 71.97 & 8.27 & 10.18 & 0.613 & 0.676 & 0.411 & 0.504 & 1.025 & 1.180 \\
\hline \multirow{2}{*}{$150 \%$} & 0 & 44.47 & 57.87 & 4.75 & 6.83 & 0.507 & 0.577 & 0.315 & 0.414 & 0.822 & 0.991 \\
\hline & $\mathrm{Fe}$ & 69.27 & 67.27 & 7.72 & 9.54 & 0.593 & 0.658 & 0.398 & 0.487 & 0.991 & 1.145 \\
\hline $\operatorname{LSD}_{\mathrm{at}}$ & & 1.25 & 1.12 & 0.12 & 0.08 & 0.024 & 0.006 & 0.008 & 0.007 & 0.027 & 0.009 \\
\hline
\end{tabular}

Data in Table 3 revealed the effect of nitrogen fertilization and iron foliar application on $\mathrm{N}, \mathrm{P}, \mathrm{K}$ and Fe contents in the dry matter of leaves at the stage of marketing. Also, VC mg $100 \mathrm{~g}^{-1} \mathrm{FW}$.

Regarding the effect of nitrogen fertilization, the data show that the application of nitrogen at $(50,75$, 100,125 and $150 \%$ ) from the recommended dose by (MASR) resulted in significant increase in the $\mathrm{N} \%$ value in spinach leaves, while such effect for $\mathrm{P}, \mathrm{K}, \mathrm{Fe}$ and $\mathrm{VC}$ content were realized at the rate of $100 \% \mathrm{~N}$ in single form, the lowest mean values were associated with $\mathrm{N}$ fertilization at the rate of $50 \%$. This trend was happened during both seasons of the experimentation.

A superiority effect on the mean values of $(\mathrm{N}, \mathrm{P}$, $\mathrm{K}, \mathrm{Fe}$ and $\mathrm{VC}$ content) was obtained due to an application of $\mathrm{Fe}$ in foliar way which recorded the highest mean values in the both seasons. The lowest mean values were recorded for the control treatment during both seasons of the experiment.

Table 3. Effect of nitrogen fertilization levels and Fe as foliar way on (N, P, K, Fe and VC content) of spinach plant during 2014-2015 and 2015-2016 seasons.

\begin{tabular}{|c|c|c|c|c|c|c|c|c|c|c|c|}
\hline \multicolumn{2}{|c|}{ Treatments } & \multicolumn{2}{|c|}{ N\% } & \multicolumn{2}{|c|}{ P\% } & \multicolumn{2}{|c|}{ K\% } & \multicolumn{2}{|c|}{ Fe ppm } & \multicolumn{2}{|c|}{$\begin{array}{c}\mathrm{VC} \\
\left(\mathrm{mg} \mathrm{100g^{-1 }} \mathrm{FW}\right)\end{array}$} \\
\hline & & $1^{\text {st }}$ & $2^{\text {nd }}$ & $1^{\mathrm{st}}$ & $2^{\text {na }}$ & $1^{\mathrm{st}}$ & $2^{\text {nda }}$ & $\mathbf{1}^{\mathrm{st}}$ & $2^{\text {nd }}$ & $1^{\text {st }}$ & $2^{\text {na }}$ \\
\hline \multirow[b]{2}{*}{$50 \%$} & 0 & 2.22 & 2.32 & 0.404 & 0.354 & 3.21 & 3.07 & 40.98 & 40.27 & 35.63 & 40.53 \\
\hline & $\mathrm{Fe}$ & 2.89 & 2.32 & 0.472 & 0.433 & 3.63 & 3.95 & 69.12 & 65.37 & 47.95 & 51.64 \\
\hline \multirow{2}{*}{$75 \%$} & 0 & 2.26 & 2.60 & 0.416 & 0.376 & 3.30 & 3.31 & 43.87 & 43.87 & 38.09 & 43.51 \\
\hline & $\mathrm{Fe}$ & 2.96 & 2.50 & 0.482 & 0.451 & 3.71 & 4.03 & 73.80 & 68.87 & 50.53 & 53.67 \\
\hline \multirow{2}{*}{$100 \%$} & 0 & 2.33 & 2.68 & 0.427 & 0.384 & 3.38 & 3.38 & 45.99 & 47.07 & 36.98 & 44.26 \\
\hline & $\mathrm{Fe}$ & 2.98 & 3.18 & 0.489 & 0.460 & 3.75 & 4.11 & 75.95 & 70.33 & 49.20 & 54.94 \\
\hline \multirow{2}{*}{$125 \%$} & 0 & 2.38 & 2.71 & 0.417 & 0.369 & 3.28 & 3.25 & 42.03 & 42.10 & 34.25 & 42.63 \\
\hline & $\mathrm{Fe}$ & 3.06 & 3.43 & 0.476 & 0.443 & 3.65 & 4.12 & 71.15 & 67.17 & 46.51 & 52.65 \\
\hline \multirow{3}{*}{$150 \%$} & 0 & 2.45 & 2.91 & 0.397 & 0.362 & 3.21 & 3.14 & 39.04 & 38.53 & 32.98 & 41.37 \\
\hline & $\mathrm{Fe}$ & 3.12 & 3.55 & 0.467 & 0.430 & 3.59 & 3.88 & 67.24 & 63.73 & 45.15 & 50.75 \\
\hline & & 0.20 & 0.30 & 0.006 & 0.009 & 0.06 & 0.21 & 0.36 & 0.92 & 0.13 & 0.19 \\
\hline
\end{tabular}

Data shown in Table 4, the effect of $\mathrm{N}$ fertilization levels and foliar Fe spraying on nitrate and nitrite accumulation as well as nitrate reductase (NR) activity in spinach leaves at the commercialization stage.

The data obtained in Table 4 indicated that, the average values of $\mathrm{NO}_{3}-\mathrm{N}$ and $\mathrm{NO}_{2}-\mathrm{N} \mathrm{mg} \mathrm{kg}{ }^{-1}$ in spinach leaves were significantly increased as the level of nitrogen fertilization was increased, while the nitrate reductase enzyme activity was significantly decreased as the level of $\mathrm{N}$-fertilization was increased. On other words, the highest values of nitrate and nitrite accumulation were associated with the plants treated with $\mathrm{N}$-fertilizer at $150 \%$ of RD, while such effect has been recorded the lowest level of nitrate reductase activity.

Regarding the effect of $\mathrm{Fe}$ as foliar application data in the same Table showed that; in the first and second seasons the highest values of nitrate were recorded for the untreated plants, while the lowest values were realized with the plants treated with Fe. Furthermore, N.R activity was also, influenced by the application of Fe was applied by foliar way; the lowest level of N.R enzyme activity was realized for the untreated plants.

Table 4. Effect of nitrogen fertilization levels and $\mathrm{Fe}$ as foliar way on $\mathrm{NO}_{3}-\mathrm{N}, \mathrm{NO}_{2}-\mathrm{N}\left(\mathrm{mg} \mathrm{kg}^{-1}\right)$ and N.R.A. of spinach leaves during 20142015 and 2015-2016 seasons.

\begin{tabular}{|c|c|c|c|c|c|c|c|}
\hline \multirow{2}{*}{\multicolumn{2}{|c|}{ Treatments }} & \multicolumn{2}{|c|}{ NO3-N mg kg- } & \multicolumn{2}{|c|}{ NO2-N mg kg-1 } & \multicolumn{2}{|c|}{ NR. Activity } \\
\hline & & $1^{\text {st }}$ & $2^{\text {nd }}$ & $1^{\mathrm{st}}$ & $2^{\text {nic }}$ & $1^{\text {st }}$ & $2^{\mathrm{n}}$ \\
\hline & 0 & 621 & 594 & 5.10 & 4.87 & 0.091 & \\
\hline & & & 543 & 4.6 & 4.47 & & \\
\hline \multirow{2}{*}{$5 \%$} & & & & & 4.91 & & \\
\hline & & & J5. & 4. & 4.58 & & \\
\hline \multirow{2}{*}{100} & & & & 5. & 5.06 & & \\
\hline & $\mathrm{F}$ & & & & 6 & & \\
\hline \multirow{2}{*}{$125 \%$} & & & & & & & \\
\hline & $\mathrm{F}$ & & & & 4.67 & & \\
\hline \multirow{3}{*}{$.50 \%$} & 0 & & & & 5.32 & & 0.057 \\
\hline & & & & 4 & 4.76 & 0.099 & 0.087 \\
\hline & $S D_{\text {at } 5 \%}$ & .Ju & 21.61 & 0.06 & 0.21 & 0.005 & 0.96 \\
\hline
\end{tabular}


The mean values of soluble, insoluble and total oxalate (mg $100 \mathrm{~g}^{-1}$ F.W) found in spinach plant as influenced by single application of $\mathrm{N}$ levels and foliar application of iron are presented in Table 5 .

As shown in Table 5 there were significant increases in soluble and total oxalate mg $100 \mathrm{~g}^{-1}$ F.W recorded with ammonium nitrate at $100 \%$ of recommended dose, while the highest values of insoluble oxalate $\mathrm{mg}$ $100 \mathrm{~g}^{-1}$ F.W were recorded of $50 \%$ of nitrogen fertilizer in both seasons.

Table 5. Effect of nitrogen fertilization levels and Fe as foliar way on total, soluble and insoluble oxalate $\mathrm{mg} 100 \mathrm{~g}^{-1} \mathrm{~F}$.W of spinach leaves during 2014-2015 and 2015-2016 seasons.

\begin{tabular}{|c|c|c|c|c|c|c|c|}
\hline \multirow{2}{*}{\multicolumn{2}{|c|}{ Treatments }} & \multicolumn{2}{|c|}{$\begin{array}{l}\text { Soluble. } \\
\text { oxalate } \\
\text { mg100g }^{-1}\end{array}$} & \multicolumn{2}{|c|}{$\begin{array}{c}\text { Insoluble. } \\
\text { Oxalate } \\
\text { mg100g }\end{array}$} & \multicolumn{2}{|c|}{$\begin{array}{c}\text { Total. } \\
\text { Oxalate } \\
\text { mg100g }^{-1}\end{array}$} \\
\hline & & $1^{\mathrm{st}}$ & $2^{\text {nd }}$ & $1^{\text {st }}$ & $2^{\text {nd }}$ & $1^{\mathrm{st}}$ & $2^{\mathrm{nd}}$ \\
\hline \multirow{2}{*}{$0 \%$} & 0 & 560 & 572 & 293 & 311 & 854 & 884 \\
\hline & $\mathrm{Fe}$ & 656 & 632 & 282 & 28 & 938 & 919 \\
\hline \multirow{2}{*}{$75 \%$} & 0 & 583 & 580 & 287 & 29 & 870 & 879 \\
\hline & $\mathrm{Fe}$ & 678 & 653 & 275 & 272 & 953 & 926 \\
\hline \multirow{2}{*}{$100 \%$} & 0 & 589 & 595 & 290 & 306 & 879 & 901 \\
\hline & $\mathrm{Fe}$ & 685 & 660 & 276 & 273 & 962 & 934 \\
\hline \multirow{2}{*}{$125 \%$} & 0 & 574 & 588 & 289 & 297 & 863 & 885 \\
\hline & $\mathrm{Fe}$ & 665 & 646 & 280 & 286 & 945 & 932 \\
\hline \multirow{3}{*}{$\begin{array}{l}150 \% \\
\end{array}$} & 0 & 554 & 575 & 292 & 303 & 846 & 877 \\
\hline & $\mathrm{Fe}$ & 649 & 639 & 283 & 279 & 932 & 918 \\
\hline & $\mathrm{LSD}_{\text {at } 5 \%}$ & 7.44 & 6.74 & 4.69 & 5.73 & 7.59 & 9.60 \\
\hline
\end{tabular}

Data at the same Table clear that, the effect of foliar application of iron were significantly affected data of the previously mentioned traits of spinach leaves due to the foliar application of iron comparing with the control treatment. In the same way, the adding of $\mathrm{Fe}$ decreased significantly the average values of insoluble oxalate $\mathrm{mg} 100 \mathrm{~g}^{-1}$ while increased soluble and total oxalate over the control. Data clearly showed that; spinach plants tended to accumulate more soluble and total oxalate as a result of foliar applied of Fe than that obtained from the untreated plants. On the contrary of this trend; a significant decrees was happened in insoluble oxalate which, treated with Fe compared with the untreated plants. The same trend was realized during the both seasons of the experiment.

\section{Discussion}

Results mentioned previously can be discussed as follow:

Results of the previously mentioned traits indicated that; an application of $\mathrm{N}$-fertilization at the rates of this investigation significantly increased the average values of dry weigh, chlorophyll contents, N, P, K, Fe and VC in the leaves of spinach plant tell $100 \%$ of RD. increasing the rate of $\mathrm{N}$-fertilizer from $100 \%$ to $150 \%$ of $\mathrm{RD}$ significantly decreased the mean values of all the aform mentioned traits during both seasons of the experimentation. The increases in these parameters in spinach leaves due to raising the nitrogen doses tell the rate of $100 \%$ may be attributed to the beneficial effect of nitrogen on stimulating the meristematic activity producing more tissues and organs since nitrogen is a constituent of proteins, nucleic acid and many important substances of plant cell. It can be noticed that in spite of the high significant increase in these parameters tell $100 \%$ of RD more increasing $\mathrm{N}$-fertilizer tell the rate of $150 \% \mathrm{RD}$ significantly increased the average values of fresh weight of spinach leaves only, which mean that the increase was in moisture percent in leaves not in the dry matter.

These results in accordance with the findings of Shaheen et al., (2012); El-Mergawi et al., (2014); Zhang et al., (2014); Abdelraouf, (2016); Awaad et al., (2016) and Mahlangu et al., (2016).

Results also indicated that at any rates of nitrogen fertilization; foliar applied of iron has been recorded a pronounced high effects on the average values of all previous parameters under study. The ideal part of iron on invigorating vegetative development of spinach plant might be alluded to the pretended by $\mathrm{Fe}$ on plant bioactivities, for example, enzymatic framework in charge of biosynthesis of amino acids, protein, chlorophyll and in addition impartment of the supplement status.

Such results were reported by El-Talawy, (1998); Abd-Allah, (2001); Salem, (2009); El-Ghamry, (2010); Abu Zinada et al., (2011) and EL-Aila et al., (2015).

The results of this investigation have proved that, increasing the rate of $\mathrm{N}$-fertilization from 50 to $150 \%$ of $\mathrm{RD}$ sharply and significantly increased the average value of nitrate and nitrite accumulation in spinach leaves, while such effect significantly decreased the activity of nitrate reductase enzyme in spinach plant. Moreover, foliar application of $\mathrm{Fe}$ in combination with any rate of $\mathrm{N}$ fertilizer has been corrected this trend. These results may be explained on basis of; under heavy nitrogen application spinach plants may absorb great quantity of nitrogen than its assimilation capacity. The different between Nabsorption and assimilation may be great and the unutilized nitrogen well be stored as nitrate and nitrites in plant tissues. In respect to the effect of Fe spraying on decreasing the content of nitrate and nitrite in spinach plant, such finding could be explained on the basis of the beneficial and stimulation effect of iron on the activity of nitrate and nitrite enzymes.

These results are confirmed with those obtained by Hanafy et al., (1997); El-Talawy, (1998); Abd-Allah, (2001); Gulser, (2005); Hammad et al., (2007); Salem, (2009); El-Ghamry, (2010); Commission Regulation, (2011); Vattani et al., (2012); Zdravkovic et al., (2012); Qiu et al., (2014) and Sakara, (2016).

Finally, a favorable effect on oxalate formation in spinach leaves due to an addition of iron in foliar way combined with any level of $\mathrm{N}$-fertilization as compared to the plants treated with the same levels of nitrogen in single form. Such effect may be due to the role played by Fe on activating the metabolism thought it's important in enzymatic system in the cell of spinach plant.

These results in agreement with those obtained by Tei et al., (2006); Stagnari et al., (2007); Zhang et al., (2009): Musa et al. (2011); Lin et al., (2014); Svein et al, (2015) and Sakara, (2016).

\section{CONCLUSION}

Under the same conditions of this investigation it can be recommended that, the highest safe yield of spinach plant and the best quality parameters were realized for the plants treated with $\mathrm{N}$-fertilization at the rate of $100 \%$ from the recommended dose by the ministry of agriculture and soil reclamation as soil 
addition in combination with Iron at the rate of $300 \mathrm{ppm}$ in foliar way.

\section{REFERENCES}

Abd-Allah, G. A. (2001): Effect of heavy nitrogen application on yield and chemical composition of some vegetable crops. Ph.D. Thesis, Soil, Dep. Fac. Agric. Mans. Univ. Egypt.

Abdelraouf A. A. E, (2016): The Effects of Nitrogen Fertilization on Yield and Quality of Spinach Grown in High Tunnels. Department of Natural Resources and Agricultural Engineering, Damanhur University, Egypt.

Abu Zinada, I.; M. Abou Auda, and E. E. S. Ali, (2011): Impact of soil lead pollution and iron foliar application on Spinacea oleracea (L.). Advances in Agriculture \& Botanics-International Journal of the Bioflux Society 3.

Awaad, S. M.; R. A. Badr, M. A. Badr and A. H. Abdelrahman, (2016): Effects of different nitrogen and potassium sources on lettuce (lactuca sativa L.) yield in a sandy soil. Federation of Eurasian Soil Science Societies,

Black, C. A. (1965): Methods of soil analysis. Part 2. Amer. Soci. of Agric. [NC] Publisher, Madison, Wisconsin.

Bohn, T.; L. Davidson, T. Walczyk and R. F. Hurrell, (2004): Fractional magnesium absorption is significantly lower in human subject from a meal served with an oxalate-rich vegetable, spinach, as compared with a meal served with kale, a vegetable with low oxalate content. British J. Nutrition 91: 601606.

Bremner, J. M.; and C. S. Mulvany, (1982): Nitrogen total Pp 595. 616. "Methods of Soil Analysis". Part2: Chemical and Microbiological Properties. Amer. Soc. of Agron., Inc., Madison, Wis., USA.

Chapman, H. D.; and Pratt, (1961): "Methods of soil analysis" Part 2 A. S. S. Madison Wisconsin.

Commission Regulation (EU) (2011): No 1258/2011 of 2 December amending Regulation (EC) No. 1881/2006 as regards maximum levels for nitrates in foodstuffs. Official journal of the European Union, pp. 15-17.

Crawford, N. M. and W. H. CamPbell, (1990): Fertile fields. The plant cell 2: 829-835.

Dehkharghanian, M.; A. Herve and A. V. Mookambeswaran, (2010): Study of flavonoids in aqueous spinach extract using positive electrospray ionization tandem quadrupole mass spectrometry. Food Chem., 121: 863-870

Dewis, J., and F. Feritas, (1970): Physical and Chemical Methods of Soil and Water Analysis, FAO, Rome, soil Bulletin, No. 10.

EL-Aila, H.I.; S.A.A EL-Sayed and A. A. Yassen, (2015): Response of Spinach Plants to Nanoparticles Fertilizer and Foliar Application of Iron. International Journal of Environment 4: 181-185.

El-Ghamry, A. M. (2010): Nitrate Accumulation as Affected by Nitrogen Fertilization and Foliar Application of Micronutrients in Rocket Plant. Molecular Environmental Soil Science at the Interfaces in the Earth's Critical Zone pp 103-109.
El-Mergawi, R. A.; K. N. Al-Redhaiman, and H. F. Abouziena, (2014): Comparison of antioxidant activity and antioxidant components in lettuce, onion and tomato obtained with different levels and forms of nitrogen fertilization. J. Agric. Sci. and Tech., 4 (7): 597-604. 28 ref.

El-Talawy, M. M. (1998): Effect of nitrogen and some micronutrient application on spinach (Spinacia oleracea L.) M.Sc. Thesis Fac. of Agric., Moshtohor, Zagazig Univ.

FAO. (2000). Guidelines and reference materials on integrated soil and nutrient management and conservation for farmers' field schools. Report AGL/MISC/27/2000. FAO, Rome.

Gomez, K. A., and A. A. Gomez, (1984): "Statistical Procedures for Agricultural Research". John Wiley and Sons, Inc., New York.pp:680.

Gotteni, A. L.; L. G. Verloo and G. Camerlynch, (1982): Chemical Analysis of Soil Lap of Analytical and Agro Chemistry, state Univ., Ghent, Belgium.

Gulser, F. (2005): Effects of ammonium sulphate and urea on $\mathrm{NO}_{3}^{-}$and $\mathrm{NO}_{2}-$ accumulation, nutrient contents and yield criteria in spinach. Sci. Horti. $106: 330$ 340.

Hageman, R. H. and A. J. Reed, (1980): Methods in Enzymology. Vo. 69 Part C (Ed Anthony San Pietro) Academic Press New York P 270.

Hammad, S. A.; M. A. Abou-Seeda, A. M. El-Ghamry, and E. M. Selim, (2007): Nitrate accumulation in spinach plants by using $\mathrm{N}$-fertilizer types in alluvial soil. J. Applied Sci. Res., (6): 511-518.

Hanafy, A. H.; N. F. Kheir, and N. B. Talaat, (1997): Physiological studies on reducing the accumulation of nitrate in Jew's mallow and radish plants. Bull. Fac. Agri., Univ. Cairo, 48: 158-164.

Jackson, M. L. (1967): "Soil Chemical Analysis Advanced Course" Puble. By the auther, Dept. of Soils, Univ. of Wisc., Madison 6, Wiscensin, U.S.A.

Jones, J.; B. J. B. Wolf and H. A. Mills, (1991): Plant analysis Handbook: A Practical Sampling, Preparation, Analysis and Interpretative Guide. Micro-Macro Publishing, Athens, Ga.

Lin, X. Y.; X. X. Liu, Y. P. Zhang, Y. O. Zhou, Y. Hu, Q. H. Chen, Y. S. Zhang and C. W. Jin, (2014): Short-term alteration of nitrogen supply prior to harvest affects quality in hydroponic-cultivated spinach (Spinacia oleracea L.). J. the Sci. of Food and Agric., 94(5):1020-1025.

Mahlangu, R. I. S.; M. M. Maboko, D. Sivakumar, P. Soundy and J. Jifon (2016): Lettuce (Lactuca sativa L.) growth, yield and quality response to nitrogen fertilization in a non-circulating hydroponic system. Journal of Plant Nutrition., 39 (12):1766-1775.

Massey, L. K. (2007): Food oxalate: factors affecting measurement, biological variation, and bioavailability. J. Am. Diet Assoc. 107(7):1191-4; quiz 1195-6.

Mazumdar, B. C. and K. Majumder, (2003): Methods on physic-chemical Analysis of Fruits. Univ. Cokkege Agric. Calcutta Univ., 108-109. 
Musa, A.; J. A. Oladiran, M. I. S. Ezenwa, H. O. Akanya and E. O. Ogbadoyi, (2011): The effects of applied nitrogen fertilizer and leaf positions on levels of micronutrients, anti-nutrients and toxic substances in Amaranths currents, African Journal of Biotechnology, 10(48), pp. 9857-9863.

Nakata, P. A. (2003): Advances in our understanding of calcium oxalate crystal formation and function in plants. Plant Sci., 164(6): 901-909.

Olsen, S. R. and L. E. Sommers, (1982): Phosphorus. Pp 403-130. "Methods of soil Analyssi". Part2: Chemical and Microbiological properties. Am. Soc. of Agron., Inc. Madison, Wis, USA.

Peters, I. S.; B. Combs, I. Hoskins, I. Iarman, M. Kover Watson and N. Wolf, (2003): Recommended Methods of Manure Analysis. Univ.Wisconsin, Cooperative extension Publ., Madison.

Piper, C. S. (1950): Soil and plant analysis. Inter Science Publishers Inc. New York.

Qiu, W.; Z. Wang, C. Huang, B. Chen and R. Yang, (2014): Nitrate accumulation in leafy vegetables and its relationship with water. Journal of Soil Science and Plant Nutrition, 14 (4), 761-168.

Sadasivam, S. and A. Manickam, (1996): Biochemical Methods, second edition, New age inter. India.

Sakara, E. M. H. (2016): Effect of Nitrogen, Calcium and Selenium Nutrition on Chemical Composition and Nutrition Value of Spinach Plant (Spinacia Oleracea L.). Ph.D. Thesis, Soil, Dep. Fac. Agric. Mans. Univ. Egypt.

Salem, N. F. G (2009): Effect of different sources and levels of $\mathrm{N}$-fertilizers and foliar application of some micronutrients on nitrate accumulation in radish and parsley plants. M.Sc. thesis, Fac. Sci., Al-Azhar Univ.

Shaheen, A. M.; F. A. Rizk, E. H. A. El-Samad, and Z. S. A. El-Shal, (2012): Growth, yield and chemical properties of spinach plants as influenced by nitrogen fertilizer forms and micro-elements foliar application. J. Applied Sci. Res., (February):777-785.
Singh, J. P. (1988): A rapid method for determination of nitrate in soil and plant extracts. Plant and Soil. 110: 137-139.

Stagnari, F.; V.D. Bitetto, and M. Pisante, (2007): Effects of $\mathrm{N}$ fertilizers and rates on yield, safety and nutrients in processing spinach genotypes. Scientia horticulturae 114: 225-233.

Svein, O. S.; F. Yndgaard and J. Axelsson, (2015): Nitrate and oxalate in germplasm collections of spinach and other leafy vegetables, Emirates Journal of Food and Agriculture, 27(9): 698-705.

Tei, F.; P. Benincasa, and M. Guiducci, (2006): Effects of nitrogen form or solution $\mathrm{pH}$ on cadmium content and quality of spinach, Acta. Horti, (700): 133-136.

U.S. Salinity Laboratory Staff (1954): Diagnosis and Improvement of Saline and Alkali Soils. USDA Agric. Hand Book No. 60, Washington, D.C.

Vattani, H.; N. Keshavarz and N. Baghaei, (2012): Effect of sprayed soluble different levels of iron chelate Nano fertilizer on nutrient uptake efficiency in two varieties of spinach, Intl. Res. J. Appl. Basic. Sci., 3 (S), 26512656,

Zdravkovic, M.; D. Cvikic, N. Pavlovic, J. Zdravkovic, R. Pavlovic, L. Boskovic Rakocevic, and M. Uric, (2012): Accumulation of nitrate in spinach depending on forms and doses of nitrogen. Acta Horti, (960): 305-309.

Zhang, J.; Z. Bei, Y. Zhang and L. Cao, (2014): Growth Characteristics, Water and Nitrogen Use Efficiencies of Spinach in Different Water and Nitrogen Levels, Sains Malaysiana, 43(11):1665-1671,

Zhang, Y. P.; X. W. Chen, Z. X. Zhang, M. Z. Chen, K. Chai and L. X. Wang, (2005): Influences of calcium treatment on the growth characters and shelf lives of Chinese cabbage. Chenese Agric Sci. Bulletin, 21: 223-226, 261 (in Chinese with English abstract).

Zhang, Y.; Y. Li, J. Wei, M. Sun, Y. Tian and Z. Li, (2009): Effects of Nitrogen and Calcium Nutrition on Oxalate Contents, Forms, and Distribution in Spinach. J. Plant Nutrition, 32 (12): 2123-2139.

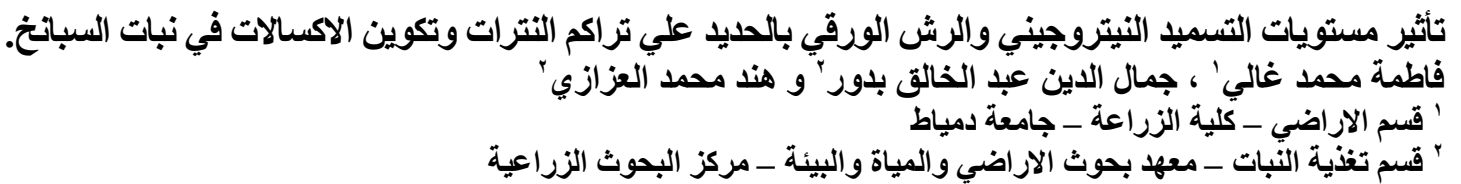

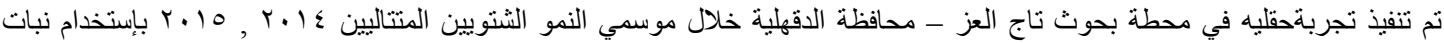

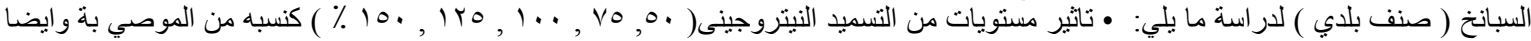

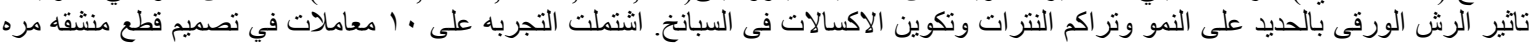

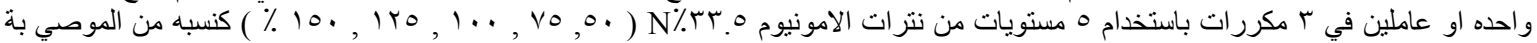

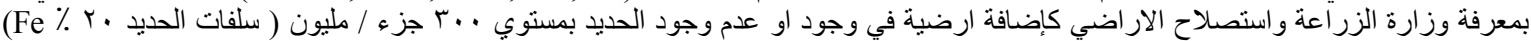

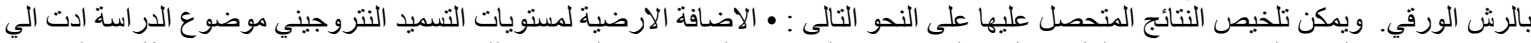

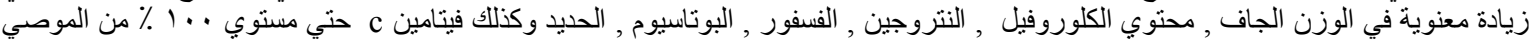

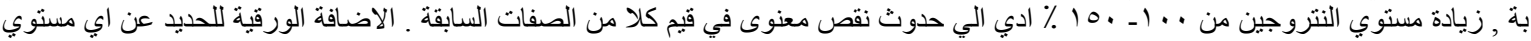

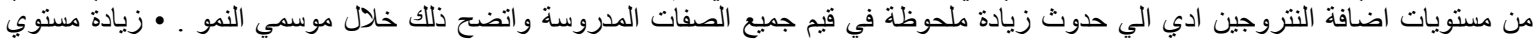

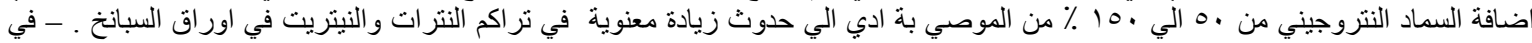

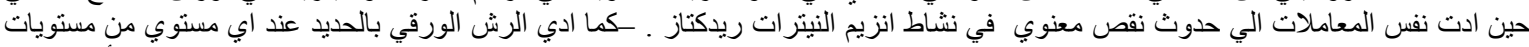

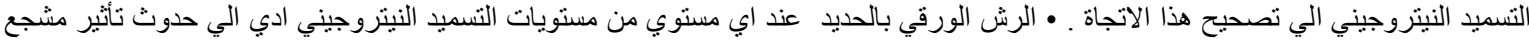

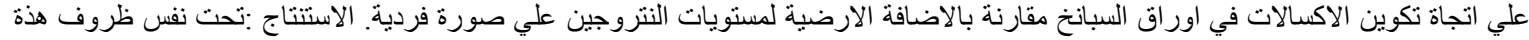

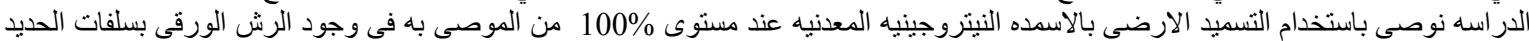
لتحقيق محصول امن من السبانخ . 